УДК 373.211.24/.378.147 (043.5)

UDC 373.211.24/.378.147 (043.5)

DOI: $10.31475 /$ ped.dys.2018.24.03

НАТАЛІЯ МИСЬКОВА,

викладач

(Украӥна, Хмельницький, Хмельницька гуманітарно-педагогічна акаделія, вул. Проскурівського підпілля, 139)

NATALIIA MYSKOVA,

lecturer

(Ukraine, Khmelnytskyi, Khmelnytskyi Humanitarian-Pedagogical Academy, Proskurivskoho Pidpillia Str., 139)

ORCID: 0000-0001-7832-4409

\title{
Педагогічний тренінг як форма підготовки майбутніх вихователів закладів дошкільної освіти до реалізації ідей сталого розвитку
}

\section{Pedagogical Training as a Form of Preparing Future Educators of Pre-School Education Institutions to Implement Sustainable Development Ideas}

На основі теоретичного аналізу виокремлено види психологічного та соціально-педагогічного тренінгу. Наведено характерні риси, недоліки та переваги тренінгу як фборми організацї пізнавальної діяльності. Визначено методи та вправи інтерактивного навчання базовили $у$ структурі педагогічного тренінгу. Наведено таксонолію когнітивних (пізнавальних) цілей Б. Блула як визначальну при виборі фборли організацї навчання. Висунуто пропозищї щодо застосування окремих вправ інтерактивного навчання відповідно кожної структурної частини тренінгу. Акцентовано увагу на використанні педагогічного тренінгу у підготовці майбутніх вихователів закладів дошкільної освіти до реалізації ідей сталого розвитку. У иьому контексті розкрито мету та завдання педагогічного тренінгу, зазначено відповідність принципів педагогічного тренінгу моральним принципал психологічної допомоги. Відмічено необхідність використання ребблексивних вправ та загострено увагу на відмінності між аналізом змісту від аналізу діяльності на тренінгу. Зазначено залежність ефективності роботи групи від особистісних та пробесійних якостей тренера.

Ключові слова: тренінг, педагогічний тренінг, інтерактивне навчання, тренінгова група, вправи інтерактивного навчання, вправи на рефблексію, тренінгові заняття, сталий розвиток, таксонолія когнітивних иілей Б. Блума.

On the basis of theoretical analysis, the types of psychological and socio-pedagogical training as forms of purposeful changes of human phenomena with the purpose of harmonization of professional and personal life have been singled out. The characteristic features and disadvantages of training as a form of organization of cognitive activity have been presented. The advantages of the training have been outlined: activity, combination of information and emotional attitude towards it, increase of level of motivation, group's ability to collective thinking and decision making, practical examination and consolidation of the received knowledge. The emphasis is placed on the use of pedagogical training in preparing future educators of preschool education institutions for the implementation of sustainable development ideas. In this context, the purpose and the tasks of the pedagogical training have been revealed, the conformity of principles of pedagogical training to the moral principles of psychological assistance have been indicated. The attributes of training have been singled out: training group; training circle; specially equipped premises and accessories for training (flipchart, markers, etc.); coach; group rules; atmosphere of interaction and communication; interactive teaching methods; structure of the training session; evaluation of the effectiveness of training. The methods and exercises of interactive training have been determined in the structure of educational pedagogical training.

The taxonomy of B. Bloom's cognitive goals has been given as a determining factor in the choice of the form of organization of training. The proposals on application of certain interactive training exercises according to each structural part of the training (introductory, main, final) have been put forward. The effectiveness of using moving exercises has been emphasized to switch the attention of the participants of the training. The necessity of using reflexive exercises has been mentioned and the attention has been paid to the differences between the analyses of the content from the analysis of the activity at the training. The dependence of the group's performance on the personal and professional qualities of the trainer has been noted.

Key words: training, pedagogical training, interactive training, training group, interactive learning exercises, reflex exercises, training sessions, sustainable development, taxonomy of cognitive goals of B. Bloom. 
Вступ / Introduction. Національною стратегіею розвитку освіти в Україні на 2012-2021 pp. визначено, що «одним із ключових напрямів державної освітньої політики має стати розвиток наукової та інноваційної діяльності в освіті, підвищення якості освіти на інноваційній основі, переорієнтація змісту освіти на цілі сталого розвитку» (Національна стратегія розвитку освіти в Україні на 2012-2021рр., 2012 р.) Розроблення основних підходів до національної освіти для сталого розвитку відбулося в межах Міжнародного проекту «Освіта для сталого розвитку в дії». Протягом 2014-2017 рр. розроблено, апробовано та внесено до переліку освітніх програм інтегрований курс «Дошкільнятам про освіту для сталого розвитку», який представлено програмами та методичними матеріалами для роботи з дітьми кожної вікової групи. Розроблені представниками української команди Міжнародного проекту «Освіта для сталого розвитку в дії (О. Пометун, І. Сущенко, Н. Гавриш та іншими) практичні семінари для вихователів закладів дошкільної освіти хоч i сприяють загостренню уваги до питань охорони довкілля, налагодженню ефективної взаємодії та формують певний практичний досвід організації освітнього процесу, проте не здатні за такий короткий термін змінити моделі поведінки учасників, сформувати у них особистісні ціннісні орієнтації у контексті ідей сталого розвитку. Окрім того, зміст семінарів розрахований на досвідчених педагогів. Відтак, актуальності набувае дослідження форм, методів та прийомів підготовки майбутніх вихователів дошкільних навчальних закладів до реалізації ідей сталого розвитку.

Мета та завдання / Aim and Tasks. Мета дослідження полягає у з'ясуванні сутності тренінгу, науковому обгрунтуванні та визначенні оптимальних методів та прийомів підготовки майбутніх вихователів закладів дошкільної освіти до реалізації ідей сталого розвитку. Завдання дослідження: з'ясувати сутність поняття «педагогічний тренінг»; визначити мету, завдання та структуру педагогічного тренінгу як форми підготовки майбутніх вихователів закладів дошкільної освіти до реалізації ідей сталого розвитку; здійснити добір ефективних методів відповідно мети та завдань кожної структурної частини педагогічного тренінгу.

Методи / Methods. Методами дослідження e вивчення наукової літератури щодо видів тренінгів, їх структури та принципів; порівняння понять «педагогічний тренінг» і «тренінг»; аналіз педагогічної моделі реалізації ідей сталого розвитку та методів інтерактивного навчання; узагальнення отриманої інформації та конкретизація мети, завдань, структури та методів педагогічного тренінгу як форми підготовки майбутніх вихователів закладів дошкільної освіти до реалізації ідей сталого розвитку.

Результати / Results. З'ясування сутності тренінгу започатковано у дослідженнях О. Главник (2006), С. Макшанова (1997), Л. Петровської (2007), М. Форверга (1984) та інших. На думку К. Мілютіної, у сучасній літературі «тренінгом називають досить різні варіанти групової роботи: особистісні перетворення дорослих, активне навчання студентів, організаційно-ділову гру на виробництві» (Мілютіна К., 2004). Найбільш прийнятним, на думку дослідниці, можна вважати трактування поняття «тренінг», запропоноване С. Макшановим. Тренінг - це багатофункціональна форма цілеспрямованих змін психологічних феноменів людини, групи або організації з метою гармонізації професійного та особистого буття людини (Мілютіна К., 2004). У Великому тлумачному психологічному словнику тренінг визначаеться як «будь-яка навчальна програма або набір процедур, розроблених для того, щоб в результаті їх здійснення був одержаний кінцевий продукт у вигляді організму, здатного на деяку певну реакцію (реакції) або участь в складній діяльності, яка вимагае певних умінь» (Шаповал В., 2004). О. Главник та О. Бевз зауважують, що тренінг - це не лише процес пізнання, спілкування, а й ефективна форма опанування знань, інструмент для опанування вмінь та навичок, форма розширення досвіду (Главник О., Бевз О., 2006). У дослідженні О. Шевчук тренінг - це форма соціально-педагогічної діяльності, спрямована на набуття життєвої компетентності шляхом збагачення як знаннями, так i життево-практичним та емоційноособистісним досвідом завдяки використанню інтерактивних засобів навчання (Шевчук О., 2013).

Характерні риси тренінгів виокремлено К. Мілютіною: тренінги потребують чітко визначеної групи учасників; вирізняються едністю часу, місця та дії (все обговорюеться тут і тепер на особистому досвіді учасників і тренера); переважає активність учасників групи та їх особистий досвід, а не інформація, отримана від тренера; заняття спрямовані не лише на формування знань, а й на розширення практичного досвіду учасників та групи в цілому (Мілютіна К., 2004). Серед переваг тренінгової форми навчання виокремлено: активність групи, поеднання інформації та емоційного ставлення до неї, підвищення рівня мотивації, здатність групи до колективного мислення та прийняття рішень, практична перевірка та закріплення отриманих знань. Серед недоліків тренінгу зазначено: непридатність для подання великого за обсягом суто теоретичного матеріалу (формул, історичних відомостей тощо); підбір групи з однаковим рівнем теоретичної підготовки; відносно невелика кількість членів тренінгової групи; вимагае високого рівня майстерності викладачатренера (Мілютіна К., 2004).

Види тренінгу визначено I. Табачник: тренінг партнерського спілкування, тренінг сенситивності 
та тренінг креативності, що пов'язані із психогімнастичними вправами, які спрямовані на формування та розвиток умінь, навичок і настанов ефективного спілкування (Табачник І., 2013).

Дещо по-іншому виокремлюе види тренінгів О. Шевчук: психокоректувальний (загальне найменування тренінгової роботи, направленої на зміну психічної сфери людини 3 кінцевою метою вдосконалення самосвідомості, поведінки, професійної діяльності людей або груп); методичний (спосіб навчання фрахівців 3 виконання тренінгової роботи); психотерапевтичний (різновид психокорегувального тренінгу, націленого на отримання психотерапевтичного ефекту); тренінг особистісного зросту (направлений на вдосконалення особистісних якостей і самосвідомості людини, що сприяе оптимізації ii поведінки і самореалізації); навчальний (націлений на придбання індивідом нових знань, розвиток умінь і навиків в певних різновидах соціальної активності людини); організаційний тренінг, робота з індивідом, робота штучною групою, робота з природною групою, робота з навчально-тренувальною групою, аутотренінг, тренінг з гомогенною групою, відкритий, професійний (проводиться з людьми певних професій в цілях підвищення їх професійно значущих психологічних якостей або підвищення ефрективності спільної професійної діяльності), тренінг міжособистих відносин та ін., (Шевчук О., 2011).

Принципи тренінгу К. Мілютіна ототожнюе з моральними принщипами психологічної допомоги, серед яких виокремлюе принципи: добровільності, рівноправності, активності, дослідницької позиції, конфіденційності (Мілютіна К., 2004).

Особливості організації освіти для сталого розвитку в закладі дошкільної освіти, на думку Н. Гавриш та О. Пометун, зумовлені специфікою розвитку психічних процесів дошкільників, їхнім світоглядом, а важливими складовими методики впровадження освіти для сталого розвитку $\epsilon$ самопізнання, самонавчання дітей через діяльність, спрямування дітей на прийняття самостійних рішень у повсякденному житті, виконання дій у напрямі сталого розвитку (Гавриш Н., Пометун О., 2018).

Практичне значення впровадження курсу «Дошкільнятам - освіта для сталого розвитку», як зауважують Т. Сімайкіна та О. Орлова, полягає у наявності у педагогів закладів дошкільної освіти можливості удосконалювати роботу з вихованцями та їх родинами, змінювати власний стиль життя та особисте ставлення до повсякденних речей; отримувати важливі результати роботи, щінні для розроблення стратегії сталого розвитку в Україні загалом (Орлова О., Сімайкіна Т., 2015). Саме тому, в даному напрямку визначено наступні головні завдання: залучення педагогів до взаємо навчання; використання творчого потенціалу для активізації та розвитку творчих можливостей колег; використання лідерських здібностей педагогів для забезпечення ї потреб у визнанні та ін. Серед визначених ефективних форм роботи з педагогами: самоосвіта, методичні діалоги, самодіагностика, самоаналіз діяльності, тренінгові заняття (Орлова О., СімайкінаТ., 2015).

Обговорення / Discussion. Аналіз досліджень із питань використання тренінгу як форми організації пізнавальної діяльності; особливостей педагогічної моделі та ролі педагога у побудові освітнього процесу відповідно до основних положень освіти для сталого розвитку дозволяе визначити тренінг як форму підготовки майбутніх вихователів до реалізації ідей сталого розвитку.

Таким чином, педагогічний тренінг у контексті даного дослідження - це форма організації пізнавальної діяльності майбутніх вихователів, яка базуеться на інтерактивному навчанні та спрямована на розвиток професійних якостей, формування системи знань, умінь, навичок та особистісних ціннісних орієнтацій у контексті ідей сталого розвитку. Таке трактування даного поняття уточнюе та конкретизуе проаналізовані у дослідженні визначення та вирізняється наявною дидактичною метою. Завдання інших дослідників, що очевидно, полягало у аналізі психологічного та соціально-педагогічного тренінгу.

Як і будь-яке навчальне заняття, стверджують О. Главник, Г. Бевз, тренінг має певну мету: інформування та набуття учасниками тренінгу нових навичок та умінь; опанування новими технологіями; зменшення чогось небажаного (проявів поведінки, стилю неефективного спілкування, особливостей реагування тощо); зміна погляду на проблему; зміна погляду на процес навчання як такий, що може приносити наснагу та задоволення (Главник О., Бевз О., 2006).

Відтак, мету педагогічного тренінгу як форми підготовки майбутніх вихователів закладів дошкільної освіти до реалізації ідей сталого розвитку вбачаємо у забезпеченні теоретичної й практичної підготовки студентів до формування готовності до взаємодії з дошкільниками на засадах сталого розвитку, виховання професійно значущих якостей особистості сучасного педагога, створення умов для формування емоційного компоненту педагогічної діяльності на основі ціннісного ставлення до довкілля та соціального оточення, підготовка до практичного здійснення завдань педагога у сучасних умовах дошкільної освіти; розвиток умінь педагогічного прогнозування.

Завдання педагогічного тренінгу: створити умови для оволодіння сутності освіти для сталого розвитку, організацією діяльності за інноваційною освітньою програмою «Дошкільнятам - про освіту для сталого розвитку»; формувати світогляд майбутніх вихователів на засадах сталого розвитку, 
вчити імплементувати ідеї сталого розвитку в освітній процес закладу дошкільної освіти; сприяти розвитку творчої особистості майбутніх вихователів через оволодіння методичними знаннями та вміннями використання інтерактивних вправ у взаємодії з дошкільнятами; виховувати ціннісні оріентири на засадах сталого розвитку.

Організація педагогічного тренінгу як фрорми підготовки майбутніх вихователів закладів дошкільної освіти до реалізації ідей сталого розвитку повинна відбуватися з дотриманням принципів добровільності, рівноправності, активності, дослідницької позиції, конфріденційності. До прикладу, принщип добровільності полягає у можливості кожного учасника відмовитися від висловлення власної позиції з приводу предмету обговорення; принщип рівноправності означає забезпечення рівних прав усіх учасників на висловлення власної думки, участі в обговоренні, активності тощо.

Серед атрибутів тренінгу виокремлено тренінгову групу; тренінгове коло; спещіально облаштоване приміщення та приладдя для тренінгу (фліпчарт, маркери тощо); тренера; правила групи; атмосферу взаємодії та спілкування; інтерактивні методи навчання; структуру тренінгового заняття; оцінювання ефрективності тренінгу (Главник О., Бевз О., 2006).

Тренінгова група, за О. Главник та Г. Бевз, - це спеціально створена група, учасники якої за сприяння ведучого (тренера) включаються в інтенсивне спілкування, спрямоване на досягнення визначеної мети та виконання поставлених завдань. Тренінгова група зазвичай включає 15-20 осіб. Така кількість людей дозволяе оптимально використати час та ефективно навчати людей (Главник О., Бевз О., 2006).

Тренінгові заняття, підкреслюють О. Главник та Г. Бевз, можуть бути різної тривалості: від 1,5-3 годин (2-4 академічні години) до декількох днів поспіль (Главник О., Бевз О., 2006). Визначено, що для підготовки майбутніх вихователів закладів дошкільної освіти до реалізащії ідей сталого розвитку доцільно використовувати систему педагогічних тренінгів (тривалістю по дві академічні години кожен), пов'язаних за змістом та спрямованих на досягнення означеної мети та вирішення окреслених завдань.

Тренінг проводить тренер, який є одночасно і таким самим учасником групи, i, водночас, каталізатором усіх процесів, що відбуваються в групі. У тренінгу широко використовуються методи, які спрямовані на стимулящію взаємодії учасників. Всі вони об'єднуються під назвою інтерактивні техніки і забезпечують взаємодію та власну активність учасників під час динамічного навчального процесу (Главник О., Бевз О., 2006).

Педагогічний тренінг базується на використанні методів інтерактивного навчання. Інтерактивне навчання О. Пометун трактуе як організащію педагогом за допомогою певної системи способів, прийомів, методів освітнього процесу, заснованого на: суб'єкт-суб'єктних стосунках педагога й учня (паритетності); багатосторонній комунікації; конструюванні знань учнем; використанні самооцінки та зворотного зв’язку; постійній активності учня (Пометун О., 2013).

Мету інтерактивного навчання О. Пометун вбачає у створенні педагогом умов навчання, за яких учень сам відкриватиме, здобуватиме й конструюватиме знання та власну компетентність у різних галузях життя. Саме це є принциповою відмінністю цілей інтерактивного навчання від цілей традиційної системи освіти (Пометун О., 2013). При конкретизації цілей інтерактивного навчання О. Пометун опирається на таксономією когнітивних (пізнавальних) цілей Б. Блума, яка активно обговорюеться в сучасній українській педагогічній громаді. Відповідно до цієї таксономії, знання лише перший, найпростіший рівень цієї іерархії. Далі маємо ще п'ять рівнів цілей, до того ж перші три (знання, розуміння, застосування) є цілями нижчого порядку, а наступні три (аналіз, синтез, оцінювання) - вищого порядку. Систематизатор когнітивних установок, за Б. Блумом, представлено у такий спосіб: 1) знання (здатність дізнаватися, відтворювати спеціальну інформацію, включаючи фракти, усталену термінологію, критерії, методологічні принципи й теорії); 2) розуміння (здатність буквально розуміти значення будь-якого повідомлення), яке представлено трьома видами: розуміння-переклад - сприйняття викладеного й перенесення в іншу фрорму (інші слова, графрік тощо); розуміння-інтерпретація - перебудова ідей у нову конфігурацію; розуміння-екстраполяція оцінювання та прогнозування, виходячи 3 раніше отриманої інформації; 3) застосування (уміння брати й застосовувати в новій ситуащії принщипи або процеси, що раніше вивчалися, без зовнішньої вказівки); 4) аналіз ( поділ матеріалу на окремі складові, визначення ї х відношень і розуміння моделі їх організації); 5) синтез (творче поєднання частин або елементів у нове ціле); 6) оцінювання (формування ціннісних суджень про ідеї, рішення, методи тощо) (Пометун О., 2013). При чому, О. Пометун зауважуе, що способи та прийоми, які використовуються в традиційному навчанні, дозволяють досягти лише перших трьох рівнів навчальних цілей. Методи інтерактивного навчання також забезпечують досягнення цілей перших трьох рівнів, причому ефективніше за традиційне навчання, дозволяючи здебільшого досягти цілей вищого порядку. Технологія інтерактивного навчання містить іще один блок цілей, реалізація яких сприяе розвитку в учнів соціальної компетентності (уміння вести дискусію, працювати в групі, розв'язувати конфлікти, слухати інших 
тощо) (Пометун О., 2013).

Під час планування, організації та проведення педагогічного тренінгу варто пам'ятати про структуру тренінгу та окреслені завдання кожної із частин. Так, тренінг, за О. Главник та Г. Бевз, складається з вступної, основної та завершальної частини. Завдання вступної частини: створення сприятливого психологічного простору; засвоєння правил роботи групи; налагодження зворотного зв’язку «учасник-група» та «група-учасник»; створення ситуації рефлексії. Триває, зазвичай вступна частина до 15 хвилин для тренінгів тривалістю 1,5-3 год., та до 30 хвилин - для тренінгів тривалістю 6-8 год., (Главник О., Бевз О., 2006).

Зважаючи на визначену тривалість педагогічного тренінгу як форми підготовки майбутніх вихователів закладів дошкільної освіти до реалізації ідей сталого розвитку, варто зауважити, що вступна частина його повинна тривати не довше 10 хвилин. Для успішності тренінгу потрібно на початку заняття визначити очікування кожного та всієї групи в цілому від роботи на тренінгу. З цією метою у вступній частині доцільно використовувати вправи: «Вітер дме», «Герб», «Градусник», «Спільна угода», «Знайомство», «Комплімент», «Очікування», «Подаруй квітку», «Прийняття правил», тощо.

Завдання основної частини, за О. Главник та Г. Бевз, полягають в оцінщі рівня поінформованості щодо проблеми; актуалізації проблеми та конкретних завдань для її вирішення; надання інформації, засвоення знань, прищеплення умінь, навичок; підбиття підсумків щодо змісту роботи (Главник О., Бевз О., 2006). Педагогічний тренінг сприяе активізації пізнавальної діяльності майбутніх вихователів за умови активної свідомої взаємодії усіх його учасників. Тренер не подає знання в готовому вигляді, а створюе умови для дослідницько-пошукової активної діяльності учасників. У центрі уваги - самостійне навчання учасників та інтенсивна їх взаємодія. Відповідальність за результативність діяльності несуть однаковою мірою усі, без винятку, учасники тренінгу. Варто пам'ятати, що від налаштування тренера на взаємодію, від його настрою та активної позищії залежить успіх взаємодії та досягнення мети тренінгу.

Тривалість основної частини розраховуеться як різниця загального часу тренінгу та суми тривалості вступної та завершальної частин. У основній частині варто використовувати вправи, які сприяють мотивації навчальної діяльності й актуалізації опорних знань, уявлень; засвоєння нових знань, формування вмінь, навичок, емоційно-ціннісних орієнтацій і ставлень; узагальнення, систематизації знань, організації рефлексії пізнавальної діяльності. До таких О. Пометун відносить вправи: «Два - чотири - всі разом», «Мікрофон», «Мозковий штурм», «Мультиголосування», «Незакінчені речення», «Обговорення проблеми в загальному колі», «Рольова гра», «Робота в парах», "Ажурна пилка», «Взаємне навчання», «Коло ідей», «Навчаючи - вчуся», «Один залишаеться / три йдуть», «Ролі в груповому навчанні», «Ротаційні трійки», «Акваріум», «Відгадай», «Дерево рішень», «Займи позицію,, «Карусель», «Безперервна шкала думок» та інші (Пометун О., 2013).

Позитивні моменти зазначених методів підкреслюе Л. Зданевич: «студенти працюють разом i краще засвоюють матеріал за короткий час; вправа може замінити пояснення нового матеріалу; метод заохочуе учасників допомагати один одному в отриманні потрібної інформації; студенти самі беруть участь у процесі викладання» (Л. Зданевич, 2013).

До завдань завершальної частини О. Главник та Г. Бевз віднесли: підбиття підсумків щодо процесу роботи; оцінка отриманого досвіду, налаштування учасників на атмосферу звичайного життя. Закінчити тренінг необхідно на піднесеній мажорній ноті із висловленням сподівання наступної приемної зустрічі. Щоразу тренінгові заняття повинні закінчуватися певними вправами, до яких О. Главник та Г. Бевз відносять: «Минуле - сьогодення - майбутнє», «Лінія життя», «Вечір спогадів», «Лист до себе в майбутне» тощо (Главник О., Бевз О., 2006). Серед вправ, які О. Пометун радить використовувати з означеною метою, найбільшою популярністю користуеться «Закінчи речення». Варіанти цієї вправи можуть бути різними, до прикладу: «Ще вчора я, а сьогодні я...», «Я впевнена, що...», «Знаю напевне, ...» та інші (Пометун О., 2013).

Для переключення уваги учасників, частини тренінгового заняття варто розмежовувати рухавками - вправами для забезпечення належного рівня рухової активності, попередження втоми та розсіювання уваги. Найбільш поширеними є: «Іподром», «Сонечко сяє», «Варенички», «Я дошкільник, ти - дошкільник» тощо. Такі вправи не лише попереджають втому, а й сприяють гуртуванню групи, подоланню бар'єрів у спілкуванні. Зазначені вправи також сприяють професійному становленню майбутніх вихователів закладів дошкільної освіти, оскільки зміст та правила ігор е зрозумілими для дітей дошкільного віку, відповідають їх віковим та психологічним особливостям та можуть використовуватися у роботі з дошкільниками в якості ігор-забав.

Добираючи методи, прийоми взаемодії під час тренінгу важливо досконало проаналізувати суть, особливості та варіанти застосування кожного, визначити мету та очікуваний результат. Пам'ятаючи про те, що важливе місце у тренінгу займає рефлексія, слід відводити на редрлексивні вправи достатньо часу. Варто розмежовувати підбиття підсумків щодо змісту діяльності від аналізу процесу 
діяльності. Аналіз змісту діяльності полягае, фрактично, у відповіді на запитання: «Про що дізналися? Що нового почули? Що занепокоїло? Що викликало здивування?» і т. п. Аналіз процесу полягае, по суті, у пошуку відповідей на запитання «Що зроблено? Яким чином дізналися? Навіщо це робили?» та ін.

Висновки / Conclusions. Таким чином, теоретичний аналіз проблем застосування тренінгу як форми пізнавальної діяльності дозволяе зробити наступні висновки. У науково-педагогічних джерелах означеної проблеми існують декілька трактувань сутності тренінгу: психологічного та соціально-педагогічного. Дослідниками окреслено цілі, принципи, окремі методичні аспекти організації тренінгу. Виокремлення характерних рис сприяло визначенню видів тренінгу, переважна кількість яких стосуеться розв'язання проблем психологічного характеру. Проведений аналіз дозволив з'ясувати сутність, мету, завдання, принципи, особливостей планування, організації та проведення педагогічного тренінгу як форми підготовки майбутніх вихователів закладів дошкільної освіти до реалізації ідей сталого розвитку.

Перспективу подальших розвідок вбачаємо у дослідженні ефективності системи педагогічних тренінгів щодо підготовки майбутніх вихователів закладів дошкільної освіти до виховання дітей дошкільного віку на засадах сталого розвитку.

\section{Список використаних джерел і літератури / References:}

1.Гавриш, Н. \& Пометун, О. (2018). Сталий розвиток: стосуеться кожного. Дошкільне виховання, 3, 2-5. / Havrysh, N. \& Pometun, O. (2018). Stalyi rozvytok: stosuietsia kozhnoho [Sustainable Development: Concerns Everyone] Doshkilne vykhovannia, 3, 2-5. [in Ukrainian]

2.Главник, О. \& Бевз, О. (упор.) (2006). Технологї̈ навчання дорослих. Київ: Главник. / Hlavnyk, O. \& Bevz, O. (upor.) (2006). Tekhnolohii navchannia doroslykh [Adult Education Technologies]. Kyiv: Hlavnyk [in Ukrainian]

3.Зданевич, Л. В. (2013). Професійна підготовка майбутніх вихователів до роботи з дезадаптованими дітьми: теорія і методика: моногр. Житомир: вид-во ЖДУ ім. I. Франка. / Zdanevych, L. V. (2013). Profesiina pidhotovka maibutnikh vykhovateliv do roboty z dezadaptovanymy ditmy: teoriia i metodyka: monohrafiia [Professional Training of the Future Educators for Work with Deadapted Children: Theory and Methodology]. Zhytomyr: vyd-vo ZhDU im. I. Franka [in Ukrainian]

4.Мілютіна, К. Л. (2004). Теорія та практика психологічного тренінгу: навч. посіб. Київ: МАУП. / Miliutina, K. L. (2004). Teoriia ta praktyka psykholohichnoho treninhu [Theory and Practice of Psychological Training]. Kyiv: MAUP [in Ukrainian]

5.Орлова, О. \& Сімайкіна,Т. (2015). Дошкільникам - освіта для сталого розвитку. Вихователь-методист дошкільного закладу, 10, 40-48. / Orlova, O. \& Simaikina,T. (2015). Doshkilnykam - osvita dlia staloho rozvytku. [Pre-Schoolers - Education for Sustainable Development]. Vykhovatel-metodyst doshkilnoho zakladu, 10, 40-48 [in Ukrainian]

6.Пометун, О. І. (2013). Енииклопедія інтерактивного навчання. Київ: А.С.К. / Pometun, О. I. (2013). Entsyklopediia interaktyunoho navchannia [Encyclopedia of Interactive Learning]. Kyiv: A.S.K. [in Ukrainian]

7.Табачник, І. Г. (2013). Тренінг спілкування як педагогічна технологія для формування професійної культури майбутніх фахівців. Наукові записки кафбедри педагогіки. Вип. 31. URL: http://nbuv.gov.ua/UJRN/Nzkp_2013_31_40_ / Tabachnyk, I. H. (2013). Treninh spilkuvannia yak pedahohichna tekhnolohiia dlia formuvannia profesiinoi kultury maibutnikh fakhivtsiv [Training of Communication as a Pedagogical Technology for the Formation of Professional Culture of the Future Specialists] Naukovi zapysky kafedry pedahohiky. Vyp. 31. URL: http://nbuv.gov.ua/UJRN/Nzkp_2013_31_40 [in Ukrainian]

8.Шаповал, В. В. (2004). Психологічний тлумачний словник. Харків: Прапор. / Shapoval, V. V. (2004). Psykholohichnyi tlumachnyi slovnyk. [Psychological Explanatory Dictionary]. Kharkiv: Prapor [in Ukrainian]

9.Шевчук, О. М. (2013). Тренінг як інноваційна форма соціально-педагогічної діяльності. Актуальні проблеми підготовки соціальних педагогів: матеріали науково-методичного семінару. Умань: ПП Жовтий. / Shevchuk, O. M. (2013). Treninh yak innovatsiina forma sotsialno-pedahohichnoi diialnosti. [Training as an Innovative Form of Social-Pedagogical Activity.] Aktualni problemy pidhotovky sotsialnykh pedahohiv: materialy naukovo-metodychnoho seminaru. Uman: PP Zhovtyi [in Ukrainian]

10.Шевчук, О. М. (уклад.). (2011). Організація і методика соціально-педагогічного тренінгу: навч. посіб. Умань: ПП Жовтий. / Shevchuk, O.M. (uklad.). (2011). Orhanizatsiia i metodyka sotsialno-pedahohichnoho treninhu. [Organization and Methodology of Social-Pedagogical Training]. Uman: PP Zhovtyi [in Ukrainian]

Дата надходження статті: «07» лютого 2018 р.

Стаття прийнята до друку: «20» квітня 2018 р.

Миськова Наталія - викладач кафедри дошкільної педагогіки, психології та фахових методик Хмельницької гуманітарно-педагогічної академії

Myskova Nataliia - lecturer of the department of pre-school pedagogy, psychology and professional methods of Khmelnytskyi Humanitarian-Pedagogical Academy

\section{Цитуйте ию статтю як:}

Миськова, Н. (2018). Педагогічний тренінг як фрорма підготовки майбутніх вихователів закладів дошкільної освіти до реалізації ідей сталого розвитку. Педагогічний дискурс, 24, 17-22.
Cite this article as:

Myskova, N. (2018). Pedagogical Training as a Form of Preparing Future Educators of Pre-School Education Institutions to Implement Sustainable Development Ideas. Pedagogical Discourse, 24, 17-22. 